\title{
Medical ethics and profit motivated medical practice - the dilemma of a modern day private health practitioner.
}

\author{
Sifile Obert \\ Chinhoyi University of Technology \\ Mhangara Mutsa \\ Chinhoyi University of Technology \\ Chavunduka Desderio \\ Chinhoyi University of Technology \\ Bhebhe Thomas Brighton \\ Chinhoyi University of Technology
}

\begin{abstract}
The rapid emergence of for-profit health care organizations over the past few years poses critical questions on the ethics of health care delivery. The study explores the ethical implications of commodification of health care service as it relates to the healing relationship between the professionals and their patients. A cross-sectional study of for-profit health practitioners in Harare Metropolitan Province, Zimbabwe was done from a representative sample size which was randomly selected from the practitioners register. Respondents answered self-administered questionnaires and key informant interviews. Data was analyzed using Epi Info Version 7, to generate descriptive and inferential statistics. A significant proportion of for-profit medical practitioners are not practicing or adhering to good ethical practices but preferring alternatives which generate income. Medical ethics should be viewed as dynamic, situational and circumstantial. The study concludes that unregulated commodification of health care services, negatively affects the healing relationship between the professionals and their patients due to lack of trust which is the fundamental backbone of the relationship. The study recommends that regulators of medical practice, Health Professions Authority and Medical and Dental Practitioners Council, should regularly review the ethical conducts standards for practitioners since they are dynamic and not to rigidly codify ethics, as they prevent better human relations and adjustments.
\end{abstract}

Key Words: Ethics, medical ethics, medical practice, private health practitioner, Zimbabwe.

\section{INTRODUCTION}

Health care services are provided to individuals or communities by health professionals or agents of the health services for the purpose of promoting, maintaining, monitoring, or restoring health (Farlex, 2012). The health care industry has traditionally included a mixture of for-profit and not-for-profit activities. Profit making was predominantly for manufacturing and marketing of pharmaceuticals and medical sundries while organizations that provided medical services to patients were predominantly not-for-profit. This is because providing health care to patients was perceived more as a social function of the government and philanthropic organizations (Gray, 1983).

Zimbabwe has not been spared from the change in the health care landscape. A growing middle class community is willing to pay for better treatment, shunning away from the ill equipped public facilities (HITREC, 2010). This has opened the door to the private sector, which is starting to play a new role, often working in partnership with investors to provide better 
health care facilities (Janssen, 2012). In 2014, a total of 894 private for-profit institutions, excluding pharmacies were providing health care to patients compared to 1431 public not forprofit (HPA, 2015). The critical question in this discourse is, how can the present economic environment, safeguard the general ethical principle that a doctor should not associate himself with commerce in such a way as to let it influence; or appear to influence, his attitude towards the treatment of his/her patients?

\section{REVIEW OF LITERATURE}

Medical professionalism as a concept can be traced back to $400 \mathrm{BC}$ with the Hippocratic Oath which described medical ethical conduct to be followed by physicians. The oath up to today is virtually taken by every physician. The aim of the medical ethics is to improve the care and health of the public by examining and promoting physician professionalism. During the era of Nightingale, physicians would take oaths that they will do all in their power to maintain and elevate the standard of the medical profession (Pledge, 2011)

The aim of each physician clearly should be to care for and protect the interest and well-being of patients to the best of the physician's abilities, while making sure his or her abilities are maintained as new discoveries are made (Catherine, 2015). Qualities of medical professionalism include sound knowledge and skills, sound work ethics, accountability, excellence, good communication skills, ethical conduct, humanism, altruism, wise application of legal understanding and self-regulation. The three fundamental principles outlined in the charter for medical professionalism are the primacy of patient welfare, patient autonomy and social justices (Foundation, 2004). The charter further gives professional responsibilities of physicians; professional competence, patient confidentiality, honest with patients, improving quality of care, maintaining appropriate relationships with patients, improving access to care, just distribution of finite resources, scientific knowledge, maintaining trust by managing conflict of interests and professional responsibility (Foundation, 2004).

Professionals have an ideology that assigns a higher priority to doing useful and needed work than economic rewards, an ideology that focuses more on the quality and social benefits of work than its profitability (Arnold, 2007).

A major reason for the decline of medical professional values is the growing commercialization of health care systems. Health care has become a huge industry largely shaped by the entry and growth of private investor owned businesses that sell health insurance and deliver medical care with a primary concern for the maximization of their income and examples include Premier Services Medical Aid Society, CIMAS and First Mutual Medical Aid in our Zimbabwean context (Shamu, 2010). The economic crisis affecting the country has played a major part in eroding the ethical commitment of physicians. Many physicians have contributed to this transformation by accepting the view that medical practice is also in essence a business. This change in attitude has critical consequences to the value system of medical practice. When physicians think of themselves as being primarily in business, professional values recede and the practice of medicine changes (Arnold, 2007).

Critical insights on the behaviour of for-profit practitioners are raised by the study on assessing if regulating for profit providers in Zimbabwe work. Unethical behaviour which was observed was described as opportunistic behaviour, emphasizing that was selfish behaviour manifesting due to poor regulatory enforcement. These unethical behaviours included; referral of patients to service where the practitioner has self-interest, over-servicing, falsely billing medical insurance and use of unlicensed cheaper doctors (Hongoro, 2000). 


\section{Conflict of Interest between profit motivated business and medical ethics}

Among other reasons which influence human action, are individual values and interests. Conflict of interest arises in a situation when an individual has more than one competing interest in the performance or outcome of an activity (Manthous, 2012). Selfish interest can subvert supervening duties or obligations, such that care must be taken to ensure that neither conscious nor unconscious selfish interest unduly influence decisions.

Far more important and difficult is the question of whether physicians could sell more orthodox pharmaceuticals. It has long been recognized that physicians who sell their own remedies have a potential conflict of interest (Bradford, 1986). In contrary, business growth strategies promote forward and backward integration, where a physician can sell drugs as a form of forward integration to maximize revenue and acquire medical aid insurance as backward integration. Closely related, physicians may seek ways in which they could receive some remuneration, beyond their usual professional fee, for prescribing medication or referrals as rebates from pharmacists or referral centres (Bradford, 1986). These linkages make the smart business partnership, but however they are condemned as unethical in the medical field.

The health care system is undergoing a rapid socio-economic revolution. Within a general environment, promoting entrepreneurial ship, the number of for-profit health enterprise has more than doubled in the past decade (Arnold, 2007). The health care is being transformed from a profession into a business (Bradford, 1986). This research will focus primarily on the ethical implications of the growth of for-profit health care institutions in the legal sense. There are some moral concerns about the rise of for-profit institutions that focus on the profit motive. Their decision making forms and organizational structures are designed to maximize profit. Serious moral criticisms for-profit healthcare have been voiced, both within and outside of the medical profession (Bradford, 1986).

The ethical concerns about the growth of for-profit health care are based on the social assumption that health care is not a commodity and should not be left to the market (Hall, 2003). Access to health care should not depend on ability to pay, but it is a human rights issue. The right to health care is basic health care adequate to meet patient's objectively determined, basic health care needs. It is perceived that the ethical acceptability of for-profit health care delivery systems depends on whether health care is viewed as a right or as a commodity (Rosoff, 2001).

As much as common codes of ethics are desirable in everybody in the health care industry, there are important limitations the code can play. Ethical codes are important in establishing professional binding values and describe a common ethical context of health care, but is of limited use in solving new and complex ethical problems (Limentani, 1999). A code may raise some unrealistic expectations about its scope and some caution is required. It is important to strike a balance between the code and realities in the environment. The main difference between reality and ethics is, reality is seen primarily in terms of the objectives, external physical world, whilst values and ethics are seen as a separate, subjective and personal attribute (Hume, 1975).

\section{Primary Ethical Theories to support decision making}

Different ethical theories can be applied to different situations to inform reasoning and support decision making. This section provides an overview of key theories applicable to health care. 


\section{Consequentialism}

Consequentialist ethics hold the perspective that the right moral response is related to the consequence or outcome of the act. It is about the rightness or wrongness of an action/policy based on its consequences (Scotland, 2008). An action or rule is right if it produces a better consequence than alternative actions or set of rules. It aims to maximize the greatest good outcome, not necessarily the best for the greatest number of people. The 'good' may refer to values or 'utility' such as happiness, being pain or symptom free or another life enhancing outcome.

\section{Deontology}

Deontology is based on duties and rights, and respects individuals as ends in themselves (Scotland, 2008). It places value on the intentions of the individual rather than the outcomes of any action. Its focus is on rules, obligations and duties. Deontology considers acting ethically as absolute adherence to these obligations and duties. The consequences can matter, but they are not the main motivation for action. One of the key criticisms is that applying a strictly deontological approach to health care can lead to conflicts of interest between equally entitled individuals which can be difficult or even seemingly impossible to resolve (Scotland, 2008).

\section{Virtue Ethics}

The virtue ethics emphasizes the moral character, or virtues of the individual. Virtue ethics have emerged due to recognized deficits in ethical theories of consequentialism and deontology for healthcare. The virtues are embedded character traits which are held to be societally valuable such as truth-telling, trustworthiness, honesty and kindness (Scotland, 2008). Virtue ethics is about an individual of good character doing the right thing.

\section{Principlism}

Principlism emphasizes four key ethical principles, autonomy, beneficence, non-maleficence, and justice which most ethical theories share (Beauchamp and Childress, 2008). It blends these with virtues and practical wisdom. This is an attempt to bring together the best elements of ethical theories which are compatible with most societal, individual or religious belief systems. By incorporating virtue ethics it enables healthcare professionals, patients and significant others, to place value or added weight on a particular principle to find a balance and rationale for decision-making (Scotland, 2008).

\section{RESEARCH METHODOLOGY}

The study sought to establish the relationship between medical ethics and commodification of health care services, thus was descriptive in nature. The study employed the use of mainly the quantitative paradigm and the case study approach.

\section{Demographic Characteristics}

\section{DATA ANALYSIS}

The respondents were predominantly male (58\%), and ages ranged from 20-79 years with $65 \%$ of them between 30-49 years. Most (58\%) of them worked in sole proprietorship surgery/clinics, practicing as general practitioners on locum basis (51\%). Almost $60 \%$ of the respondents practiced in uptown and low/middle density geographical locations.

\section{Current Ethical Practices}

The study sought the diversity of ethical opinions regarding frequent ethical dilemmas, as proxy to the respondent's ethical practices. 
Table 1: Current ethical practices of private for-profit physicians in Harare

\begin{tabular}{|c|c|c|}
\hline Variable & Characteristic & $\mathrm{N}=116(\%)$ \\
\hline \multirow{3}{*}{$\begin{array}{l}\text { Would you ever consider halting life sustaining therapy because } \\
\text { family can no longer afford, even when you feel that it is } \\
\text { premature? }\end{array}$} & Yes & $49(42)$ \\
\hline & No & $50(43)$ \\
\hline & It depends & $17(15)$ \\
\hline \multirow{3}{*}{$\begin{array}{l}\text { Would you ever prescribe a treatment that is a placebo, simply } \\
\text { because the patient wants treatment? }\end{array}$} & Yes & 57 (49) \\
\hline & No & $39(34)$ \\
\hline & It depends & $20(17)$ \\
\hline \multirow{3}{*}{$\begin{array}{l}\text { Would you ever recommend or give life sustaining therapy when } \\
\text { you judged that it is futile? }\end{array}$} & Yes & $47(41)$ \\
\hline & No & 38 (33) \\
\hline & It depends & 31 (27) \\
\hline \multirow{3}{*}{$\begin{array}{l}\text { Would you ever hide information from a patient about a terminal } \\
\text { or pre-terminal diagnosis in an effort to bolster their spirit or } \\
\text { attitude? }\end{array}$} & Yes & $15(13)$ \\
\hline & No & $93(80)$ \\
\hline & It depends & $8(7)$ \\
\hline \multirow{3}{*}{$\begin{array}{l}\text { Is it acceptable to perform a procedure that isn't medically } \\
\text { warranted, for reasons of gaining high tariff? }\end{array}$} & Yes & $26(22)$ \\
\hline & No & $75(65)$ \\
\hline & It depends & $15(13)$ \\
\hline \multirow{3}{*}{$\begin{array}{l}\text { Would you refer a patient to a physician simply to return a favor } \\
\text { to the doctor, when you don't think that the person was the best } \\
\text { qualified? }\end{array}$} & Yes & $20(17)$ \\
\hline & No & 69 (59) \\
\hline & It depends & 27 (23) \\
\hline \multirow{3}{*}{$\begin{array}{l}\text { Is it ever acceptable to overstate or falsify a patient's condition } \\
\text { when submitting claims or seeking prior authorization? }\end{array}$} & Yes & $9(8)$ \\
\hline & No & $81(70)$ \\
\hline & It depends & $26(22)$ \\
\hline \multirow{3}{*}{$\begin{array}{l}\text { Would you feel conflicted about dropping insurers that don't pay } \\
\text { well, even though some longtime patients would probably stop } \\
\text { seeing you? }\end{array}$} & Yes & $39(34)$ \\
\hline & No & $67(58)$ \\
\hline & It depends & $10(9)$ \\
\hline \multirow{3}{*}{$\begin{array}{l}\text { Would you ever "fire" a "non-compliant" patients so that you } \\
\text { don't spoil your reputation? }\end{array}$} & Yes & $18(16)$ \\
\hline & No & $66(57)$ \\
\hline & It depends & $32(28)$ \\
\hline \multirow{3}{*}{$\begin{array}{l}\text { Would you agree that you should refuse gifts or perks from } \\
\text { pharmaceutical companies because they may influence your } \\
\text { medical judgment? }\end{array}$} & Yes & $49(42)$ \\
\hline & No & $52(45)$ \\
\hline & It depends & $15(13)$ \\
\hline \multirow{3}{*}{$\begin{array}{l}\text { Would you perform an abortion in illegal situations, if the patient } \\
\text { insists to pay? }\end{array}$} & Yes & $35(30)$ \\
\hline & No & 68 (59) \\
\hline & It depends & $13(11)$ \\
\hline
\end{tabular}

\section{Adherence to good medical ethical practices}

The study also sought the adherence to good medical practices in the current economic health environment. The Table 2 summarizes the reactions of the respondents 


\begin{tabular}{|c|c|c|}
\hline $\begin{array}{l}\text { Table 2: Adherence to good medical ethical } \\
\text { practices }\end{array}$ & Characteristic & $\mathrm{N}=116(\%)$ \\
\hline \multirow[t]{4}{*}{ I use an ethical approach to conflict resolution } & Always & $39(34)$ \\
\hline & Usually & $54(47)$ \\
\hline & Occasionally & $23(20)$ \\
\hline & Almost never & $0(0)$ \\
\hline \multirow{4}{*}{$\begin{array}{l}\text { I use my authority solely to fulfill my responsibilities } \\
\text { and not for self-interest or to further the interest of } \\
\text { family, friends or associates }\end{array}$} & Always & $34(29)$ \\
\hline & Usually & $68(59)$ \\
\hline & Occasionally & $11(9)$ \\
\hline & Almost never & $3(3)$ \\
\hline \multirow{4}{*}{$\begin{array}{l}\text { I ensure equitable treatment of patients regardless of } \\
\text { socioeconomic group or payer category }\end{array}$} & Always & $39(34)$ \\
\hline & Usually & $58(50)$ \\
\hline & Occasionally & $11(9)$ \\
\hline & Almost never & $8(7)$ \\
\hline \multirow{4}{*}{$\begin{array}{l}\text { I am mindful of the importance of avoiding even the } \\
\text { appearance of wrongdoing, conflict of interest, or } \\
\text { interference with free competition }\end{array}$} & Always & $37(32)$ \\
\hline & Usually & $64(55)$ \\
\hline & Occasionally & $15(13)$ \\
\hline & Almost never & $0(0)$ \\
\hline \multirow{4}{*}{$\begin{array}{l}\text { I personally disclose conflicts of interests before } \\
\text { pursuing or entering into relationships with potential } \\
\text { business partners or patients }\end{array}$} & Always & $41(35)$ \\
\hline & Usually & $66(57)$ \\
\hline & Occasionally & $7(6)$ \\
\hline & Almost never & $2(2)$ \\
\hline \multirow{4}{*}{$\begin{array}{l}\text { I protect patients' right to autonomy, clinical efficacy, } \\
\text { and full information about their illness, treatment } \\
\text { options, and related costs }\end{array}$} & Always & $77(66)$ \\
\hline & Usually & $34(29)$ \\
\hline & Occasionally & $5(4)$ \\
\hline & Almost never & $0(0)$ \\
\hline \multirow{4}{*}{$\begin{array}{l}\text { I am a patient advocate on both clinical and financial } \\
\text { matters }\end{array}$} & Always & $16(14)$ \\
\hline & Usually & $77(66)$ \\
\hline & Occasionally & $23(20)$ \\
\hline & Almost never & $0(0)$ \\
\hline
\end{tabular}

In ethical dilemma, 34\% of respondents always use an ethical approach in conflict resolutions (Table 2). Twenty nine percent, always uses their authority solely to fulfill responsibilities and not for self-interest or to further the interest of family, friends or associates. Only 34\% always ensure equitable treatment of patients regardless of socioeconomic group or payer category. In the discharge of duty, 32\% of respondents are always mindful of the importance of avoiding, conflict of interest, or interference with free competition. Before pursuing or entering into a relationship with potential business partners or patients, 35\% always disclose conflict of interest. Sixty six percent always protect patients' right to autonomy, clinical efficacy, and full information about their illness, treatment options, and related costs. Fourteen percent are patient advocates on both clinical and financial matters.

\section{Roles of commercial strategists in health care}

The study also sought the diversity of opinions regarding advertising as a commercial strategy in healthcare. Initial respondents gave opinions on the feasibility running a profitable ethical medical business. The figures below summarizes the reactions of the respondents 


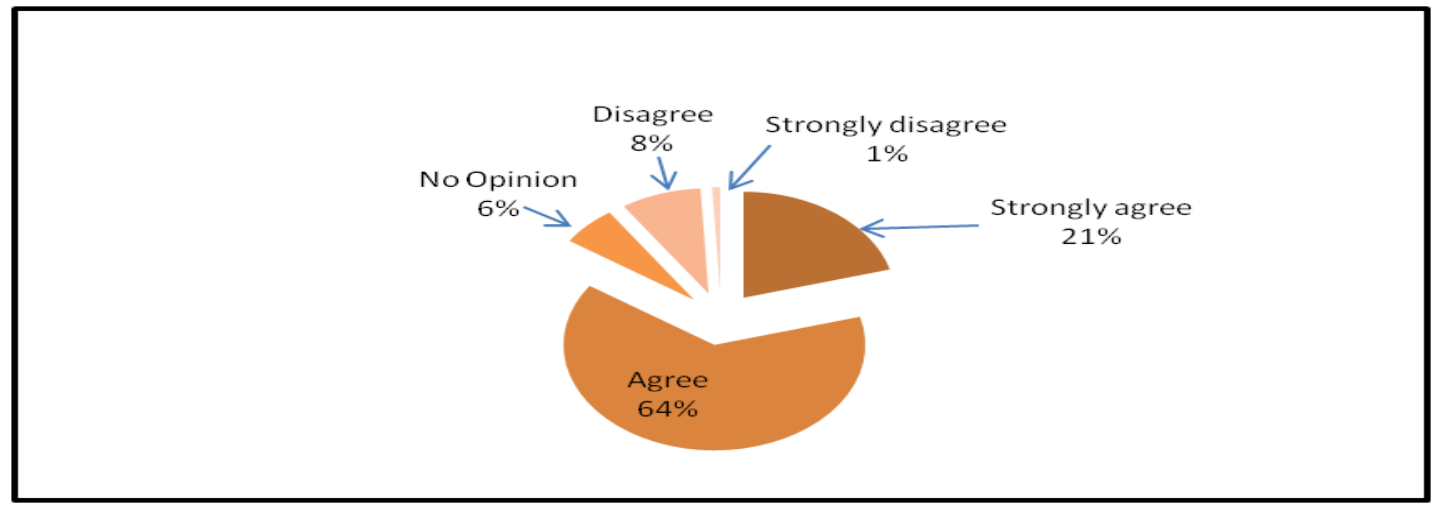

Figure 1: Opinions on feasibility of business to be both ethical and profitable

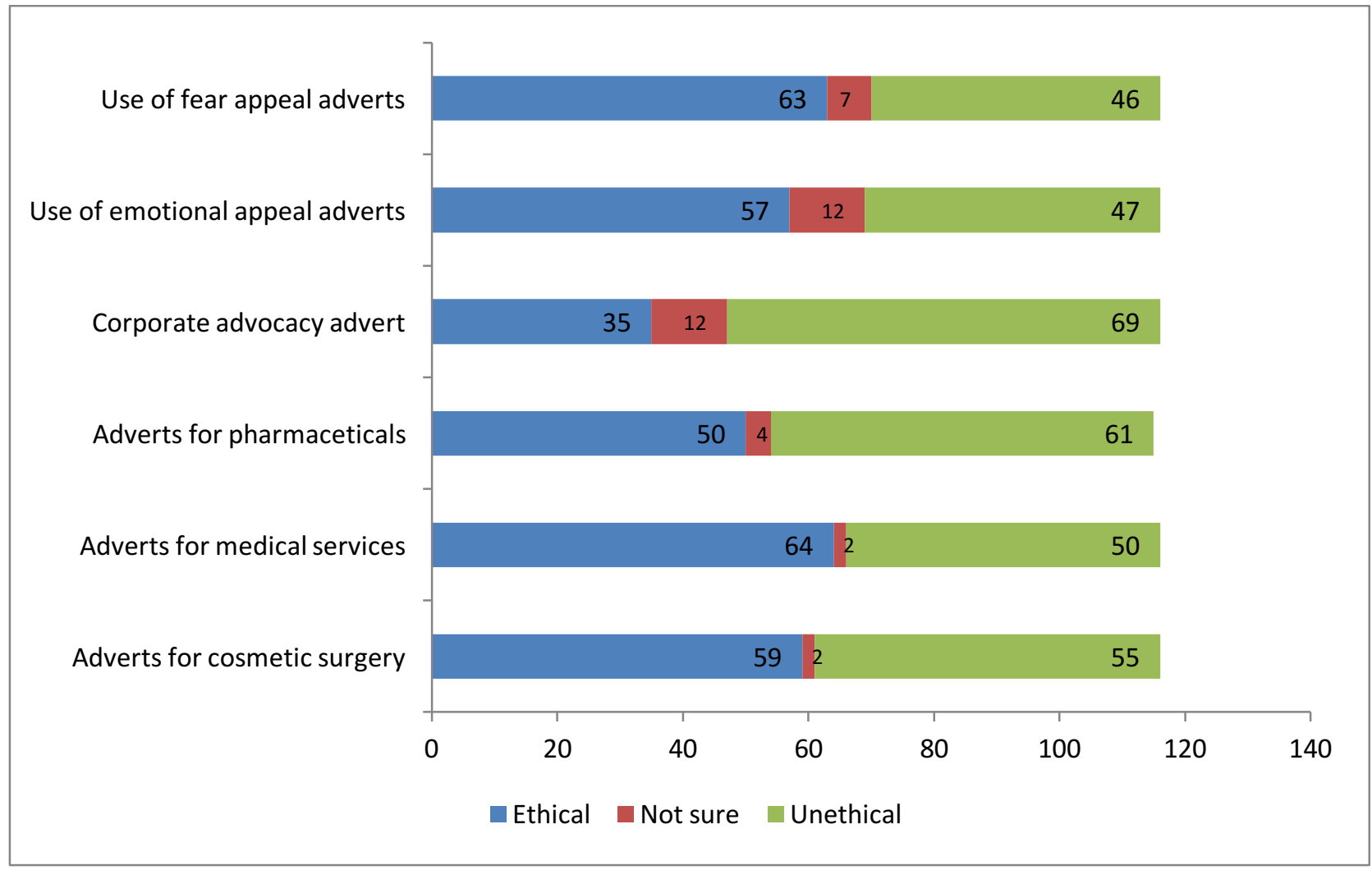

Figure 2: Ethical Views of respondents on advertising strategies in healthcare provision

The majority of respondents viewed business strategies of using fear appeal adverts, emotional appeal adverts, advert for medical services and advert for cosmetic surgery as unethical while adverts for corporate advocacy and pharmaceuticals were perceived as ethical by the majority (Figure 2). However, there was no substantial difference in proportion (less than 5\%) of those who perceived advertising cosmetic surgery as unethical and those who perceive it as ethical.

\section{Potential ethical implications of commodifying health care services}

In the event that medical services are commodified, $57 \%$ of respondents had a view that risk to others should not be tolerated; irrespective of how small the risk might be (Table 3). 
Table 3: Potential ethical issues which may arise due to commodification of health care service

\begin{tabular}{|c|c|c|}
\hline Variable & Characteristic & $\mathrm{N}=116(\%)$ \\
\hline \multirow{5}{*}{$\begin{array}{l}\text { Risks to another should never be tolerated, irrespective of } \\
\text { how small the risks might be }\end{array}$} & strongly agree & $10(9)$ \\
\hline & Agree & $56(48)$ \\
\hline & no opinion & $12(10)$ \\
\hline & Disagree & $26(22)$ \\
\hline & strongly disagree & $4(3)$ \\
\hline \multirow{5}{*}{$\begin{array}{l}\text { The dignity and welfare of the people should be the most } \\
\text { important concern in any society }\end{array}$} & strongly agree & $43(37)$ \\
\hline & Agree & $57(49)$ \\
\hline & no opinion & $8(7)$ \\
\hline & Disagree & $7(6)$ \\
\hline & strongly disagree & $1(1)$ \\
\hline \multirow{5}{*}{$\begin{array}{l}\text { What is ethical varies from one situation and society to } \\
\text { another }\end{array}$} & strongly agree & $17(15)$ \\
\hline & Agree & $73(63)$ \\
\hline & no opinion & $7(6)$ \\
\hline & Disagree & $19(16)$ \\
\hline & strongly disagree & $0(0)$ \\
\hline \multirow{5}{*}{$\begin{array}{l}\text { Moral standards should be seen as being individualistic; } \\
\text { what one person considers being moral may be judged to be } \\
\text { immoral by another person }\end{array}$} & strongly agree & $19(16)$ \\
\hline & Agree & $71(61)$ \\
\hline & no opinion & $5(4)$ \\
\hline & Disagree & $12(10)$ \\
\hline & strongly disagree & $9(8)$ \\
\hline \multirow{5}{*}{$\begin{array}{l}\text { Rigidly codifying an ethical position that prevents certain } \\
\text { types of actions could stand in the way of better human } \\
\text { relations and adjustment }\end{array}$} & strongly agree & $19(16)$ \\
\hline & Agree & $60(52)$ \\
\hline & no opinion & $12(10)$ \\
\hline & Disagree & $25(22)$ \\
\hline & strongly disagree & $0(0)$ \\
\hline \multirow{5}{*}{$\begin{array}{l}\text { No rule concerning lying can be formulated; whether a lie is } \\
\text { permissible or not permissible totally depends upon the } \\
\text { situation }\end{array}$} & strongly agree & $13(11)$ \\
\hline & Agree & $58(50)$ \\
\hline & no opinion & $12(10)$ \\
\hline & Disagree & $22(19)$ \\
\hline & strongly disagree & $11(9)$ \\
\hline
\end{tabular}

\section{Inferential Statistical Analysis}

The bivariate analysis of respondent characteristics of their perception of the notion that, it is possible for a business to be both ethical and profitable, is summarized in Table 4. 
Table 4: Factors associated with the perception that business can be both ethical and profitable

\begin{tabular}{|c|c|c|c|c|}
\hline Variable & $\begin{array}{l}\text { Agree } \\
(\mathrm{N}=98)\end{array}$ & $\begin{array}{l}\text { Disagree } \\
(\mathrm{N}=18)\end{array}$ & Odds ratio $(95 \% \mathrm{CI})$ & p-value \\
\hline \multicolumn{5}{|l|}{ Age } \\
\hline 20-39 years & 41 & 9 & $0.72(0.26-1.97)$ & 0.265 \\
\hline$\geq 40 \mathrm{yrs}$ & 57 & 9 & & \\
\hline \multicolumn{5}{|l|}{ Sex } \\
\hline Male & 58 & 9 & $1.45(0.53-3.97)$ & 0.24 \\
\hline Female & 40 & 9 & & \\
\hline \multicolumn{5}{|l|}{ Qualification } \\
\hline First Degree & 60 & 6 & $3.1(1.1-9.1)$ & $0.016^{*}$ \\
\hline Postgraduate & 38 & 12 & & \\
\hline \multicolumn{5}{|l|}{ Geographic location } \\
\hline High density residential/ & 42 & 6 & $1.5(0.52-4.32)$ & 0.234 \\
\hline $\begin{array}{l}\text { Low/middle residential } \\
\text { density }\end{array}$ & 56 & 12 & & \\
\hline \multicolumn{5}{|l|}{ Practicing experience } \\
\hline$<3$ years & 39 & 7 & $1.03(0.37-2.91)$ & 1.03 \\
\hline$\geq 3$ years & 59 & 11 & & \\
\hline \multicolumn{5}{|l|}{ Specialization } \\
\hline General Practitioner & 84 & 12 & $3(0.97-9.3)$ & $0.037^{*}$ \\
\hline Specialist & 14 & 6 & & \\
\hline \multicolumn{5}{|l|}{ Business Type } \\
\hline Individually owned & 73 & 14 & $0.83(0.25-2.77)$ & 0.399 \\
\hline Corporate & 25 & 4 & & \\
\hline
\end{tabular}

There was no significant difference ( $p>0.05$ ), between those agreed and disagreed with the view that it is possible for a business to be both ethical and profitable, by age, sex, geographic location, practicing experience and business type. Those with the first degree were three times more likely to agree with the view, than those with a post graduate qualification and the relationship was statistically significant. General practitioners were three times more likely to agree with the view than their specialist counterparts and the relationship was statistically significant $(\mathrm{p}<0.05)$. 
Table 5: Variables associated with view that medical practice has a responsibility that goes to the society beyond profit making

\begin{tabular}{|c|c|c|c|c|c|}
\hline Variable & & $\begin{array}{l}\text { Agree } \\
(\mathrm{N}=98)\end{array}$ & $\begin{array}{l}\text { Disagree } \\
(\mathrm{N}=18)\end{array}$ & $\begin{array}{l}\text { Odds ratio } \\
(95 \% \mathrm{CI})\end{array}$ & $\begin{array}{l}\text { p- } \\
\text { value }\end{array}$ \\
\hline \multirow{2}{*}{$\begin{array}{l}\text { Have you ever considered halting life- } \\
\text { sustaining therapy because family can } \\
\text { no longer afford, even if you feel that it } \\
\text { is premature }\end{array}$} & Yes & 8 & 41 & $0.53(0.21-1.35)$ & 0.093 \\
\hline & No & 18 & 49 & & \\
\hline \multirow{2}{*}{$\begin{array}{l}\text { Have you ever prescribe a treatment } \\
\text { that is a placebo, simply because the } \\
\text { patient wants treatment }\end{array}$} & Yes & 15 & 42 & $1.56(0.65-3.77)$ & 0.167 \\
\hline & No & 11 & 48 & & \\
\hline \multicolumn{6}{|l|}{ Have you ever recommended or give } \\
\hline \multirow{2}{*}{$\begin{array}{l}\text { life sustaining therapy when you } \\
\text { judged that it is futile }\end{array}$} & Yes & 4 & 43 & $0.2(0.06-0.62)$ & $0.001^{*}$ \\
\hline & No & 22 & 47 & & \\
\hline \multirow{2}{*}{$\begin{array}{l}\text { Have you ever hidden information from } \\
\text { a patient about a terminal or pre- } \\
\text { terminal diagnosis in an effort to } \\
\text { bolster their spirit or attitude }\end{array}$} & Yes & 1 & 14 & $0.22(0.03-1.74)$ & 0.059 \\
\hline & No & 25 & 76 & & \\
\hline \multirow{2}{*}{$\begin{array}{l}\text { Is it acceptable to perform a procedure } \\
\text { that isn't medically warranted, for } \\
\text { reasons of gaining high tariff }\end{array}$} & Yes & 1 & 25 & $0.1(0.01-0.81)$ & $0.003^{*}$ \\
\hline & No & 25 & 65 & & \\
\hline \multirow{2}{*}{$\begin{array}{l}\text { Would you ever "fire" a "non- } \\
\text { compliant" patients so that you don't } \\
\text { spoil your reputation }\end{array}$} & Yes & 2 & 16 & $0.39(0.08-1.80)$ & 0.112 \\
\hline & No & 24 & 74 & & \\
\hline \multirow{2}{*}{$\begin{array}{l}\text { Would you perform an abortion in } \\
\text { illegal situations, if the patient insists to } \\
\text { pay? }\end{array}$} & Yes & 2 & 33 & $0.14\left(0.03 \_0.65\right)$ & $0.002^{*}$ \\
\hline & No & 24 & 57 & & \\
\hline
\end{tabular}

There was a general consistence in answering of questions by the respondents as summarized in Table 5. Those who consider halting life-sustaining therapy because family cannot longer afford, even if they feel that it is premature, or those who prescribe a treatment that is a placebo, simply because the patient wants treatment, or those who hide information from a patient about a terminal or pre-terminal diagnosis in an effort to bolster their spirit or attitude, or those who fire" a "non-compliant" patients so that they do not spoil their reputation where less likely to agree that medical business has an ethical responsibility that goes beyond profitmaking.

Statistical significance $(\mathrm{p}<0.05)$ was found in those who give-life sustaining therapy when they judged that it is futile, those who found it acceptable to perform a procedure that is not medically warranted for reasons of gaining high tariff and those that would perform an abortion in illegal situations, if the patient insists to pay. All these groups were less likely to agree that medical practice as a business have responsibilities to society that go beyond profit making.

\section{Ethical behaviour}

\section{THEMES GLEANED FROM KEY INFORMANT INTERVIEWS}

Instances have been observed where a medical doctor pursuing a wealth maximization agenda acts in an unethical manner or in conflict of interest. These instances include, having a private surgery/clinic next to the hospital where the doctor is employed full-time and government doctors with private surgeries/clinics "poaching" affording patients from public facilities to 
their private surgeries in the guise of offering faster better medical services. Doctors who sell drugs in their rooms, tend to prescribe what they have in stock not what is the best or cheaper, same effect and available elsewhere.

\section{Role of private for-profit physicians}

Private for-profit medical organisations offer complementary alternative health services to the population. Ideally since users of private health services pay per cost, quality of services should be much better than public facilities and a doctor can be seen on demand. There is a better doctor patient ratio such that patients spend more time with the doctor resulting is a better doctor patient relationship.

Regulators find nothing wrong with doctors pursuing for-profit medical enterprise. It is a form of entrepreneurship, which just needs regulation and control, and doctors also need extra income to survive. As long as doctors fulfil their occupational obligations in an ethical manner according to the rules and regulations, there is no hindrance to private practice. The advantages of doctors pursing a profit motivated health enterprise include; provision of high quality of health services due presumably to better facility equipment and motivation of the doctor. It may overally lower the price of health services due to competition. The community overally benefits from employment creation and availability of alternative social amenities.

However, civic society in contrast, is against doctors pursing a profit motivated enterprise. It puts the risk of abuse of vulnerable patients by doctors since there is a huge asymmetry of information. They fear doctors will forget their primary function of offering health services to the community as they concentrate on how to make as much profit as possible through vulnerable unsuspecting patients. The doctors will have a conflict of interest as they choose on best medical services versus lucrative options. Consequently, it reduces trust, which is critical to the doctor patient relationship. In an effort to maximize profit, there is a risk that service providers may compromise quality of care.

\section{Recommendations for doctors in for-profit organisations}

Civic groups recommend a doctor in for-profit enterprise to be paid a fixed amount by State per month for a geographic area served. This reduces the incentive induced unethical behaviours. Regulators recommend the continuous engagement of the for-profit service providers in provision of ethical review continued health education and monitoring of practices. They further propose enforcement of price controls and monitoring of adherence to treatment guidelines.

\section{POLICY IMPLICATIONS AND RECOMMENDATIONS}

The study encourages the regulator of medical practice, the Health Professional Authority and Medical and Dental Practitioners Council, to regularly review the ethical conduct standards for practitioners since they are dynamic.

The study recommends regulators not to rigidly codify ethics, as they are situational and society dependent. With the ever changing socioeconomic environment, rigidly codifying ethical position prevents better human relations and adjustments.

The Health Professional Authority should allow health practitioners to advertise through different media channels, but should regulate the content to prevent misinformation and duress due to fear and emotional appeal adverts. 
The practice of for-profit medical practitioners should be monitored more closely by the regulators since it has an apparent conflict of interest and information asymmetry between service provider and client. Patients should be sensitized on potential pitfalls and should be given open channels of reporting unethical behaviour.

\section{References}

Arnold, R. (2007). Medical Professionalism in a Commercialised Health Care Market. JAMA , Vol 298 number 22.

Beauchamp, C. (2001). Principles Biomedical Ethics. OUP.

Bradford, G. (1986). For-Profit Enterprise in Health Care. Washington D.C: National Academic Press.

Catherine, D. A. (2015, May 12). Medical Professionalism. Medical Professionalism , pp. Vol 313, Number 18.

Farlex. (2012). Farlex Partner Medical Dictionary. Farlex Partne.

Foundation, A. C. (2004). Medical Professionalism in the New Millennium: A physician Charter. Retrieved July 12, 2015, from ABIM Foundation http:// www.abimfoundation.org/ / media/ Foundation/

Professionalism/Physician\%20Charter.ashx?la=en

HITREC. (2010). Draft Human Resource Country Profile. Harare: Ministry of Health and Child Welfare.

Hongoro, K. (2000). Regulating for profit providers. In Health Policy Planning (pp. 15(4):368-377). Oxford: Oxford University Press.

HPA. (2015). Database of Health Facilities. Harare: HPA.

Manthous. (2012). Hippocrates as Hospital employee: Balancing Beneficience and contractual duty. American Journal of Critical Care , Vol 21, No.1, pg 60-66.

Pledge, T. N. (2011). The Nightingale Pledge. Retrieved August 20, 2015, from The Nightingale Pledge: http://www.alamo.edu/sac/nursing/honors.html

Scotland, N. (2008, December 08). Ethical Theories. Retrieved July 19, 2015, from Advanced Nursing ethical Tool Kit: http://www.advancedpractice.scot.nhs.uk/legal-and-ethics-guidance /what-is-ethics/ethical-theories.aspx

Shamu, L. M. (2010). Capital flows through Medical Aid Societies in Zimbabwe's health sector, Discussion Paper Series 82. Training and Research Support Centre, SEATINI,. Harare: EQUINET. 